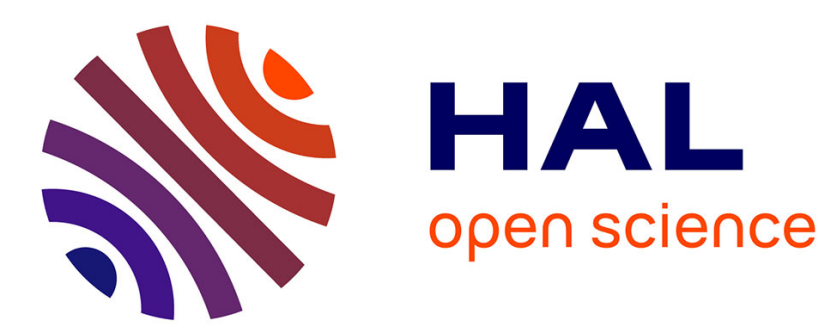

\title{
Energy and Competitiveness
}

Dominique Bureau, Lionel Fontagné, Philippe Martin

\section{To cite this version:}

Dominique Bureau, Lionel Fontagné, Philippe Martin. Energy and Competitiveness. [Research Report] 2013-06, Conseil d'Analyse Economique. 2013. hal-01299929

\section{HAL Id: hal-01299929 \\ https://hal.science/hal-01299929}

Submitted on 8 Apr 2016

HAL is a multi-disciplinary open access archive for the deposit and dissemination of scientific research documents, whether they are published or not. The documents may come from teaching and research institutions in France or abroad, or from public or private research centers.
L'archive ouverte pluridisciplinaire HAL, est destinée au dépôt et à la diffusion de documents scientifiques de niveau recherche, publiés ou non, émanant des établissements d'enseignement et de recherche français ou étrangers, des laboratoires publics ou privés. 


\section{conseil d'analyse économique}

French Council of Economic Analysis
Dominique Bureau ${ }^{a}$, Lionel Fontagnéb

and Philippe Martinc

\section{Energy and Competitiveness}

\section{Les notes du conseil d'analyse économique, no 6, May 2013}

$\mathbf{W}$ hen energy prices are expected to rise over the next twenty years, it is essential that industrial innovation efforts and the supply of goods and service offerings be directed towards energy-efficient technologies. However, a more significant increase in energy prices in France than in other countries would be detrimental to the short-term competitiveness of French industry.

The present Note outlines the terms of the trade-off France has to confront between preserving a significant part of its short-term competitiveness (its relatively low energy costs, particularly where electricity is concerned) and the necessary transformation of its mid-long-term comparative advantages (as the result of realistic energy pricing). Based on an original econometric study examining the export activities of French companies, we estimate that a $10 \%$ increase in electricity prices in France would reduce the value of exports by an average $1.9 \%$ and that the same increase in the price of gas would reduce it by $1.1 \%$. The loss in competitiveness is notably more significant for larger exporters, particularly in those sectors that depend heavily on energy. This short-term negative effect should be balanced against the signalling effect of an increase in energy prices on mid-long-term specialisations in order for France not to get left behind in the "green" innovation race. Several lessons we can be drawn from this analysis.

Firstly, the increase in energy prices should be announced in a credible way so that economic agents can include it in their calculations and revise their consumption and production choices as appropriate. In addition, in order to limit the negative effects of increasing energy costs on short-term competitiveness, we would recommend that:

- additional energy taxation be used to reduce the labour cost;

- proceeding with great caution with regards to the rate at which legacy nuclear facilities, the cost per kWh of which is particularly attractive, are decommissioned;

- a differentiated attribution of the public service charge according to energy intensity (as is the case in Germany);

- a convergence of approaches at European level with regards to network costs. 
Global energy prices are expected to rise in the medium term by $15 \%$ for coal and $50 \%$ for oil and gas over the next twenty years. ${ }^{1}$ Having said that, it is difficult to have absolute faith in these forecasts in the long-term. As was recently demonstrated by the very marked drop in gas prices in the United States following the exploitation of shale gas, the introduction of new technologies that will make it possible to exploit new deposits makes it difficult to forecast. The seven-fold increase in oil prices in dollars since 2000, however, would suggest that other factors (and in particular demand from emerging countries) will continue to drive up energy prices.

The increasing importance of environmental issues and in particular that of global warming should also result in the "true" cost of energy being taken into greater consideration when it comes to public policy. This is, in any case, the path the French government has decided to take with its reflection on the diversification of energy sources (the energy transition), which followed the long-term energy-saving plan (the Grenelle de l'Environnement agreement). Increasing fuel prices, combined with the development of renewable energy sources, will automatically increase electricity prices. With this in mind, the French Energy Regulatory Commission (CRE) anticipates a 30\% increase in the price of electricity for households by 2017 . The increases facing manufacturers will be less significant - $24 \%$ for the tarif jaune rate and $16 \%$ for customers on the tarif vert. ${ }^{2}$

The present Note aims to analyse the impact of a likely increase in energy prices on the competitiveness of France and more specifically on the performance of exporting companies. ${ }^{3}$ The decline in the competitiveness of France has been the subject of various convergent diagnoses. ${ }^{4}$ Indeed, it was the Gallois Report that inspired the French government's Pacte pour la compétitivité, la croissance et l'emploi" ("Competitiveness, Growth and Employment Pact"). More recently, this alarmist diagnosis was reiterated in the European Commission's report of April 2013 published as part of the procedure for preventing excessive macroeconomic imbalances. ${ }^{6}$

Our country finds itself in a somewhat unusual situation due to its energy mix and its very specific electricity pricing policy, with prices generally lower than those of our European competitors. On this point, the Gallois Report concluded that, "the price of electrical energy for industry is relatively low in France and represents a major advantage that has to be maintained". We agree with this assessment, despite the difficulties associated with measurement. Its implications must, however, be considered from a mid-long-term perspective, taking into account imbalances in the markets concerned.

Should the government anticipate the increase in energy costs by increasing the taxation and pricing of energy? Is it better to protect intermediate energy consumers (manufacturers) from this increase by delaying it? Should the government allow "market trends" to send a signal of scarcity to users (and energy producers) to help them adjust? In this latter case, should the increase be accompanied by appropriate subsidy plans that would make the adjustment less painful?

Whilst difficult for economic policy, these issues are particularly menacing when considered from a competitiveness perspective. Energy is a cost to French businesses and the increase in costs in France, and wage costs in particular, goes some way towards explaining the slump in France's external trade and more generally the decline in industrial employment.

In the present Note we shall be focusing on the impact of an increase in energy prices on competitiveness and attempting to distinguish between the short-term and long-term effects, which may well differ. In the short-term, with companies taking technology for granted, energy is a cost. In the longer-term, the price of energy is a signal to both manufacturers and end-consumers; the demand for buildings, production processes and products that are energy-efficient or use new forms of energy could give rise to a "national" supply, thus dynamically creating new comparative advantages for French industry and the associated services. ${ }^{7}$ The issue of competitiveness therefore takes on a different dimension in the short and long terms. In the short term, it might be seen as a company's ability to increase its export activity or enter foreign markets, in which case the cost of energy has a negative impact on competitiveness. In the long term, competitiveness at national is synonymous with growth and in particular in productivity growth which must take into account not only production efficiency and the development of new sectors but also the quality and environmental footprint of the products in question.

\footnotetext{
We would like to thank Stéphane Saussier, Scientific Advisor at the CAE, and Gianluca Orefice, Economist at the CEPII, for their help and support.

${ }^{1}$ See International Energy Agency (2012): World Energy Outlook.

${ }^{2}$ Commission de Régulation de l'Energie (2013): Le fonctionnement des marchés de détail français de l'électricité et du gaz naturel, $2011-2012$ Report, January.

${ }^{3}$ The impact of environmental policy on the competitiveness of companies has been studied in Bureau D. and M. Mougeot, (2004): Politiques environnementales et compétitivité, CAE Report, no 54, La Documentation française.

${ }^{4}$ See, for example, Fontagné L. and G. Gaulier (2008): Performances à l'exportation de la France et de l'Allemagne, CAE Report, no 81 , La Documentation française.

${ }^{5}$ Gallois L. (2012): Pacte pour la compétitivité de l'industrie française, Report to the Prime Minister, La Documentation française, 5 November.

${ }^{6}$ European Commission (2013): In-Depth Review for France in Accordance with Article 5 of Regulation (EU) no $1176 / 2011$ on the Prevention and Correction of Macroeconomic Imbalances, European Commission SWD(2013) 117 final.

${ }^{7}$ We do not undervalue the fact that competition is now a global matter. However, a flourishing domestic market might be a pre-requisite for the introduction of new activities.
} 
Whilst the increase in energy costs reflects scarcity and the need to take into account environmental costs, the correct policy is not to isolate the intermediate consumer (companies) or the final one (households)) from this reality. Insofar as foreign competitors would be facing the same cost variations, isolating French companies would result in subsidies for exports through distorted energy prices and delays in the necessary technological adjustment.

Artificially maintaining low energy costs in the road haulage sector, for example, effectively amounts to subsidising both exports and imports. Trade that is artificially supported in this way by under-pricing in the road haulage sector does not appear to be effective, particularly within the European Union, where supply chains are extremely complex. Another example is the the recent episode of the temporary tax reduction applied to fuel in order to limit the impact of the increase in oil prices on motorists; indeed, the line between protecting purchasing power and encouraging changes in consumer behaviour is a very thin one.

Furthermore, "subsidising energy" still has to be funded; in the case of France, taxing employment more heavily whilst reducing tax on energy would be a step in the wrong direction and would not tackle the core issues of price and nonprice competitiveness. Furthermore, whilst this subsidising might not be perceived as a sustainable solution, it will not prevent relocations and will have a deadweight effect only for the companies that benefit from it.

From a general economic perspective, one of the difficulties of the discussion surrounding "energy and competitiveness" is the asymmetry between certain energy-intense sectors, which are exposed to a price divergence between France and foreign competitors, and the rest of the economy, which is only marginally affected by this discussion and where the potential to create jobs depends primarily on the cost of employment.

The distorsions generated by a degree of commercial mercantilism are visible on an international scale. It would therefore be fair to say that "environmental dumping" is often a reality; the governments soften their environmental policies to improve competitiveness in certain sectors at a cost that a cost-benefit analysis would deem excessive given the environmental damage it causes. Within Europe itself, the design errors in the carbon market clearly reflect the effectiveness of pressure groups that have succeeded in introducing rather lenient global emission caps and quota allocation methods, which are a source of major deadweight effects.

The lesson to be learnt from the present Note is that economic policy is treading the thin line between a low price, desi- gned to maintain competitiveness in the short term but burdening the long-term adjustments required, and a high price that would reduce cost competitiveness and therefore industrial employment in the short term but which would provide the incentives required for the switch towards an energy-efficient energy economy.

The remainder of the present Note is structured as follows: the first section outlines the diagnosis of the loss of competitiveness in France, the second section analyses energy prices in France for manufacturers from a comparative perspective, the following section deals with the mechanisms that connect competitiveness and energy prices, the fourth section attempts to gauge how companies' export activities react to variations in energy prices and the final section outlines a series of economic policy recommendations.

\section{The loss of competitiveness in France}

An economic policy objective might be to increase French exports (i.e. exports by companies located within the country, such as Danone, Toyota, etc.) and even to increase them at the rate of global demand. In the latter case, which is generally the one upheld in economic policy discussion, it is important to ensure that global market shares are maintained. ${ }^{8}$

The cost of labour (which has been explained since 2008 by the burden of social contributions and the stagnation in productivity in relation to wages) ${ }^{9}$ has affected the cost competitiveness of French exporters, who have suppressed their prices by reducing their margins. The latter are now the lowest in the Euro zone and this phenomenon is even more pronounced in the manufacturing sector. In addition to this, there are also the well-known non-price factors (exporter demographics, lack of inclination to export on the part of medium-sized companies, lack of innovation) to take into account. The 2012 reduction in the trade deficit, owing primarily to record sales in the aeronautics industry and a lack of domestic demand, does nothing to alter the competitiveness diagnosis according to the European Commission (op.cit.). Indeed, French export market shares dropped $11 \%$ between 2006 and 2011. ${ }^{10}$

This decline in French export market shares has been the subject of much commentary. The image of this deterioration is all the more evident when considered in relation to the situation in Germany (Graph 1). With the exception of the leather, leather goods and shoe sector that was driven by the luxury brands, France's relative performance in relation to Germany in 2010 (vertical axis) was still poorer than in 2000

\footnotetext{
${ }^{8}$ In reality, it is a case of not losing more market share than the average for OECD countries, which are finding themselves forced to take a step back in the global market as new competitors emerge.

${ }^{9}$ See Askenazy P., A. Bozio and C. García-Peñalosa (2013): "Dynamique des salaires par temps de crise”, Note du CAE, no 5.

${ }^{10}$ This decline was nevertheless twice as fast between 2003 and 2008, before the divergence of wages and productivity in France. For a definition of the indicators see European Commission (2012): "Scoreboard for the Surveillance of Macroeconomic Imbalances", European Economy Occasional Papers, no 92.
} 
(horizontal axis). This included sectors where France's global market share was greater than that of Germany in 2000, namely agriculture and the food-processing industry.

\section{Ratio of global market shares of France to those of Germany \\ By sector in 2000 and 2010}

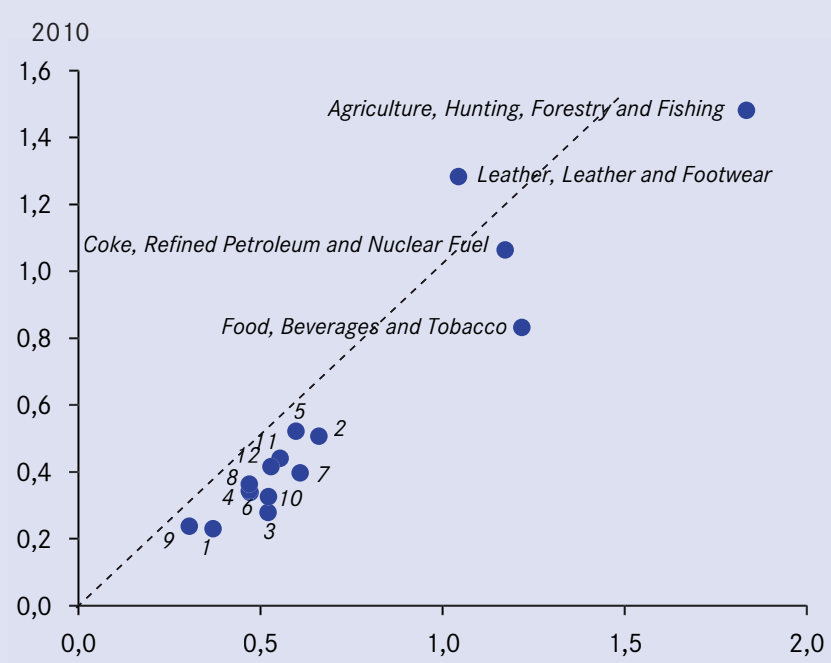

Reading: In 2000, France's global market share of the agricultural industry was almost twice that of Germany. A decade later it was just one and a half times that of Germany.

1. Mining and Quarrying; 2. Textiles and Textile Products; 3. Wood and Products of Wood and Cork; 4. Pulp, Paper, Paper, Printing and Publishing; 5. Chemicals and Chemical Products; 6. Rubber and Plastics; 7. Other Non-Metallic Mineral Products; 8. Basic Metals and Fabricated Metal Products; 9. Machinery, Nec; 10. Electrical and Optical Equipment; 11. Transport Equipment; 12. . Manufacturing, Nec; Recycling.

Source: Calculations based on BACI-CEPII.

\section{Price of electricity: the current situation}

France occupies a special position that reflects on the one hand the scale of its nuclear power network and on the other the strict pricing regulation on the part of the government. The unique nature of the French situation results in a very low electricity price not only for households but also for the majority of businesses. For historic reasons, only four European countries have lower prices than those observed in France, namely Romania, Estonia, Bulgaria and Finland (see Graph 2).

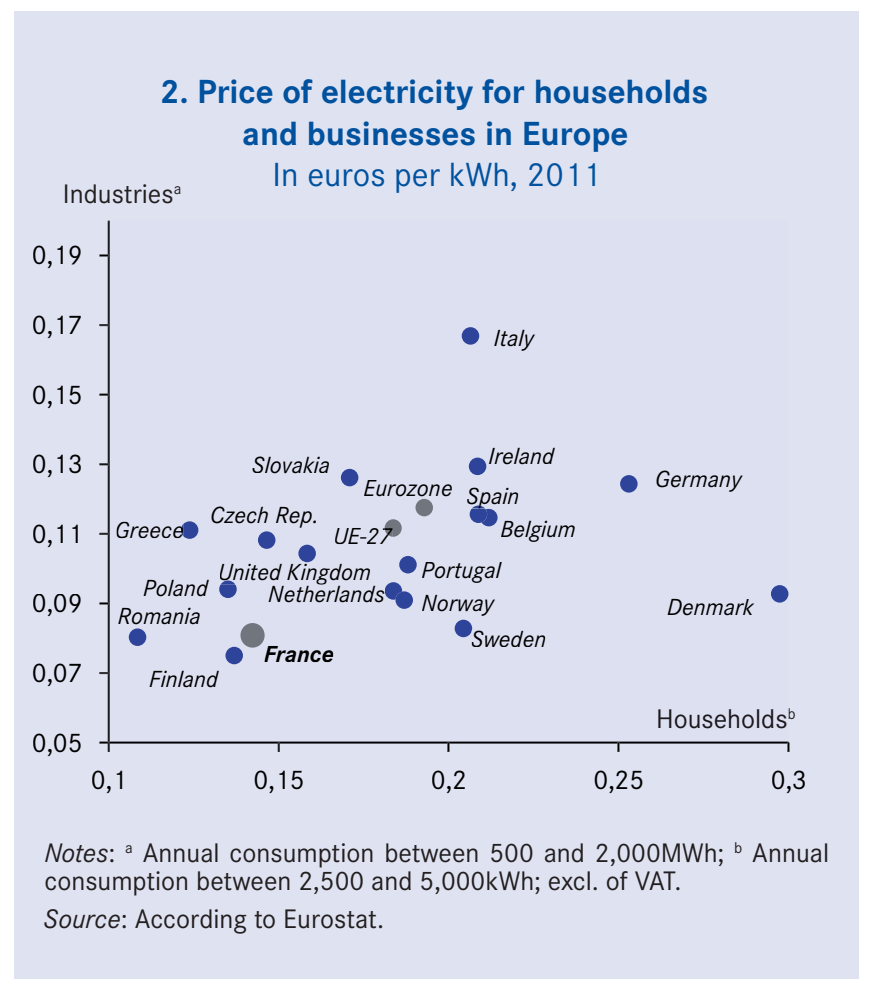

Comparison at the international level (see following table) further underlines the unique situation in France. Whilst this difference in favour of French manufacturers might have decreased over time, European prices in general more closely look like German prices - it is France that finds itself in an unusual position. Despite the marked increase in electricity prices for French manufacturers since 2008 (+16\%, the $7^{\text {th }}$ greatest increase within the OECD, behind Switzerland and Japan with $+40 \%$ and $+29 \%$ respectively), French manufacturers, according to the IEA, maintained an average advantage of $23 \%$ over their German counterparts. The handicap is nevertheless a very significant one with regards to the United States (75\%, cf. table) and could increase further given that American industrial electricity will track shale gas prices. ${ }^{13}$

\footnotetext{
${ }^{11}$ For reasons of statistical availability, only market share relating to goods is generally taken into consideration, to the consequent exclusion of services.

${ }^{12}$ For a more comprehensive analysis of electricity and gas pricing policies in Europe see Chevalier J-M. and J. Percebois (2008): Gaz et électricité : un défi pour l'Europe et pour la France, CAE report, no 74, La Documentation française. The volatility of energy prices can also affect companies. See on this matter Artus P., A. d'Autume, P. Chalmin and J-M. Chevalier (2010): Les effets d'un prix du pétrole élevé et volatil, CAE report, no 93, La Documentation française.

${ }^{13}$ The Table on page 5 cannot be directly compared to Graph 2. Indeed, Eurostat compares a typical 2,000MWh industrial contract corresponding to mediumsized plant facilities whilst the IEA compares averages prices, therefore taking into account different consumption volumes.
} 
Average price of industrial electricity in the OECD Incl. taxes (2011), in dollars/TOE

\begin{tabular}{lcc} 
& $\mathbf{2 0 0 8}$ & $\mathbf{2 0 1 1}$ \\
\hline Italy & 3370 & 3248 \\
Ireland & 2162 & 1772 \\
Hungary & 1973 & 1561 \\
Japan & 1620 & 2082 \\
Germany & 1499 & 1828 \\
OECD Europe & 1660 & 1744 \\
Belgium & 1612 & 1611 \\
Netherlands & 1545 & 1378 \\
Turkey & 1614 & 1612 \\
United Kingdom & 1697 & 1481 \\
Portugal & 1527 & 1618 \\
Poland & 1387 & 1416 \\
Greece & 1306 & 1460 \\
Denmark & 1510 & 1339 \\
France & $\mathbf{1 2 1 9}$ & $\mathbf{1 4 1 3}$ \\
OECD Total & 1270 & 1436 \\
Spain & 1455 & 1730 \\
Finland & 1127 & 1321 \\
Switzerland & 1090 & 1531 \\
Sweden & 1109 & 1212 \\
United States & 794 & 809 \\
New-Zealand & 831 & 857
\end{tabular}

Source: Agence internationale de l'énergie (2013): “End-Use Prices: Energy Prices in National Currency per TOE", IEA Energy Prices and Taxes Statistics Database.

\section{Electricity pricing}

The pricing of the electricity supplied to major manufacturers is an issue that has come under regular scrutiny, even in the days when EDF had the monopoly on production and was calling for better tariffs in the name of competitiveness. EDF pointed out that with regards to the current networks (thermal and nuclear), electrical production is fundamentally an activity where unit costs remain constant, meaning that they do not decrease for higher volumes produced. Of course, the cost of equipment is proportional to the generating capacity and the cost of fuel proportional to the energy used. This left little room for maneuver, with the marginalist pricing struture (EDF's tarif vert) passing the costs that were directly attributable to them on to the different users, thus ensuring a financial balance without cross-subsidisation between consumers. Furthermore, EDF rather appeared to be an efficient producer. Under these conditions, the idea of restoring the balance of funding between manufacturers and domestic consumers appeared to be a pure distortion of "realistic pricing". Nowadays, manufacturers also have the option of choosing their producer. Believing that the libera- lisation of the market would be in their interests, they were, however, disappointed when they noted that this was instead resulting in an increase in prices. ${ }^{14}$ This increase in prices does not mean that the country as a whole did not come out a winner, but simply that the distribution of the gains achieved through the opening up of the market favours electricity producers rather than consumers. The Nome Law rectified this situation by arranging access to the production of the legacy nuclear network.

The pricing of electricity for industrial use must distinguish between what comes under direct costs, on the one hand, and the coverage of fixed costs and the funding of public working charges, on the other.

Consumers, whoever they may be, must cover their direct costs, otherwise there is no guarantee that their demand is economically justified. "Subsidised" electricity, for example, will oust direct electricity exports, which would result in a better margin for the economy. The direct costs associated with electricity production are very closely proportional to consumption. In this respect, there is no room for a volume "discount" approach, which would lead to users making illinformed choices and being poorly prepared for future developments. Furthermore, by limiting the funding of new equipment this would also run the risk of under-investment that these very industries would later come to regret. For the same reasons of realistic pricing, it is only to be expected that $\mathrm{CO}_{2}$ quotas (the price of $\mathrm{CO}_{2}$ having slumped far too much nowadays) be fully incorporated into the pricing structure.

Generally speaking, the demand for electricity is now heavily influenced by the importance of regulated prices wich result in an inaccurate or incomplete reflection of cost. Shielding major consumers from market prices in this way will result in them making inefficient energy choices. ${ }^{15}$

The question of funding the fixed costs of the network and public service charges, which includes funding drops in learning curves relating to renewable energy sources, however, is a legitimate one. From an economic perspective, it is only rational for heavy electricity users who are also major exporters to pay less towards the fixed costs since the average cost (of the network and the public service charge) is lower for these heavy users. In fact, this is already the case since the public electricity service charge (CSPE) is capped at $€ 550,000$ per industrial site and $0.5 \%$ of the added value of the company for industrial companies using more than 7GWh. Once the CSPE cap that applies in France and the exemption from or reimbursement of taxes corresponding to the CSPE and the TURPE (French public electricity network usage charge) in Germany are taken into account, the diffe-

\footnotetext{
${ }^{14}$ The increase in prices was economically predictable, with the openness of the markets concerned resulting in an intermediate price between those that had previously been in force in the different countries. In this instance, France was, in fact, towards the lower end of the scale in terms of production costs. ${ }^{15}$ For a more comprehensive analysis see Crampes C. and T-O Léautier (2012): Dix propositions pour faire entrer l'industrie électrique française dans le XXI siècle, École d'Economie de Toulouse.
} 
rential in the cost of electricity excluding tax between French and German electro-intensive industrial users (tarif vert-type) is greatly reduced but remains around $12 \%$ more favourable to France (cf. Eurostat and the Union Française d Electricité (“French Electricity Association")). The policy governing the reimbursement of certain taxes to electro-intensive manufacturers nevertheless appears to be reaching the limits of tolerance for households in Germany, who are entirely responsible for funding it. It is certainly worth considering following Germany's lead and partially reimbursing such taxes and network charges (CSPE and TURPE), but it is first and foremost important to ensure a convergence of approaches at European level where network costs are concerned.

\section{Electricity production costs}

Above and beyond the issue of pricing, the price of electricity depends on the cost of the various fuels and equipment used. It is therefore essential to the competitiveness of our economy that these costs be controlled, something which must be taken fully into account when examining the various potential scenarios regarding the development of our electricity production facilities.

In this respect, the total cost per MWh for the various equipment that is likely to be commissioned by 2030 would appear to be noticeably higher than that of the "legacy" nuclear network, in terms of both new renewable energy sources (offshore wind farms and photovoltaic energy), new nuclear energy and gas cycles, the latter also generating large amounts of greenhouse gas emissions. There is much at stake here, since the average production cost variance over the same period is estimated at around $30 \%$, or even more, between the scenarios involving the decommissioning of existing $40 \mathrm{GWs}$ of the legacy nuclear network and those in which it would primarily be postponed until after 2030 (irrespective of the type of technology adopted for replacement). Decommissioning the facilities in question too quickly would also risk putting a strain on capacity.

\section{The price of gas}

The price of gas in France is around the European average. The use of shale gas in the United States (which accounts for nearly a third of the country's gas consumption), however, has resulted in gas there being around three times less expensive than it is in Europe. This significant difference in price has a major impact on competitiveness and choice of location on the part of companies in certain industrial sectors, such as the chemicals industry. Above and beyond its positive impact on employment and the balance of trade, the use of shale gas in France would nevertheless have a less significant impact on prices than in the United States, where prices have drop- ped $67 \%$ in five years; indeed, given that production costs will remain higher in Europe than in the United States, ${ }^{16}$ the cost of shale gas in Europe would be comparable to the estimated cost of liquefied gas imported from the United States, which would therefore maintain its competitive edge. This less significant impact on prices than in the United Stated must therefore be juxtaposed with the environmental effects of using shale gas. For want of short-term exploitation, we believe that research should be carried out into the cleanest and least costly techniques for exploiting shale gas, in accordance with one of the recommendations of the Gallois Report

Ultimately, irrespective of the energy source, it would not be appropriate to base our arguments on prices per se. These prices include production costs, distribution margins and taxes. Production costs will naturally increase as they reflect issues associated with scarcity or the increased consideration of safety in the nuclear field; taxes will increase if we want to send a message to French economic players; but what will become of the margins? This issue cannot be resolved without an accurate analysis of the conditions of competition observed in energy sectors (which are by their very nature highly concentrated). In this respect, the regulation of the sector will be key.

\section{What effects can we expect an increase in energy prices to have on competitiveness?}

Variations in a country's market shares can be partially explained by price competitiveness and this is particularly true in the case of France. The geographical or product-specific structure of the country's exports, and even non-price competition factors (such as product quality or image), also have a role to play. This reality should not, however, conceal another, namely the fact that at the product level,considering sales by a company in a particular market, the response in terms of sales volume to price variations (corrected for quality) is undeniable. Increasing prices but not quality would result in a reduction in exports (to an extent that would depend on the nature of the goods and the market structure and the degree of competitiveness thereof).

In the case at hand, a greater increase in energy prices in France than in other countries would result in a decline in the export performance of companies located in France, all other things being equal. An analysis of the competitiveness of a country should therefore take into account the fact that it is not the country that is exporting but rather the company. Companies vary in terms of productivity, size, sector of activity, presence in international markets and profitability and a particular impact on energy prices is also, therefore, likely to have varying consequences.

\footnotetext{
${ }^{16}$ See International Energy Agency (2012): Perspectives énergétiques mondiales.
} 


\section{Companies and competitiveness}

Empirical work ${ }^{\mathrm{a}}$ that uses very rich and detailed company data both for France and other European countries has achieved some very strong results with regards to the links between the competitiveness of companies, productivity and export activity, including the following:

- the export activity of a country is heavily concentrated around a small number of companies. In France, for example, $90 \%$ of aggregate exports are the work of just $5 \%$ of exporting companies. This concentration can also be observed in Germany, though to a slightly lesser degree, with $80 \%$ of aggregate exports produced by $5 \%$ of exporters. It is therefore important to analyse the impact of an increase in energy costs on the largest exporters;

- companies that export are larger and more productive than those that do not export. Their production process also uses more capital;

- companies that export also import more intermediate goods than those that do not export, which helps increase their productivity and therefore their export performance;

- exporting companies are more innovative in terms of both products and production processes and invest more heavily in R\&D.

a See, for Europe, T. Mayer and G.M. Ottaviano (2007): "The Happy Few: New Facts on the Internationalisation of European Firms", Bruegel-CEPR EFIM 2007 Report, Bruegel Blueprint Series.

\section{The short-term effects}

The price of energy is one of the many factors that determine exporters' prices in foreign markets. The various factors that determine price notably include the costs of other intermediate consumptions, the cost of labour, transport and distribution costs, any potential customs duties, the exchange rate and export margins. The relative weight of these different aspects varies from one sector to the next. In all cases, however, a more marked increase in the price of energy in France than in other countries will be detrimental in the short term to the cost competitiveness of French exporters. As is the case with any increase in cost, companies can react by increasing the price of their products, which will have a negative impact on their export sales.
This increase in cost can also have the effect of forcing some exporting companies (those that are the least productive) to abandon their export activities. Indeed, the reduction in their sales reduces their export revenue, and for some this loss of revenue will mean they are no longer able to offset the specific costs associated with export (transportation, tariffs, creation of a distribution network, etc.).

Faced with such an increase in costs, exporting companies might also decide to reduce their margins. In choosing not to pass the increased costs on to their customers (or at least not in their entirety), they will effectively experience a decrease in their margins, a decrease that could well result in an eventual loss of competitiveness. Indeed, it might even affect the ability of such companies to fund their investments and their research and development expenditure. Such investments have an impact on their future productivity and therefore their future ability to export.

\section{The mid-long-term effects}

In the longer-term, increasing energy costs could affect the country's specialisation, as is observed in the case of environmental regulations; comparative advantage in industries that use the most pollutant of technologies is reduced, resulting in relocations. A recent study ${ }^{17}$ confirmed the significant effect of environmental regulations on the international specialisation of countries in polluting industries. An increase in energy prices might also, however, encourage companies to innovate, as has been the case in the automotive industry, ${ }^{18}$ by creating the appropriate domestic market conditions for clean technologies.

In the long term, the question that needs to be answered is that of the compatibility of what French industry has to offer with the needs of a more energy-efficient economy. The question raises the issues of "green competitiveness" and a "first mover" advantage (sometimes known as the "Porter effect") ${ }^{19}$ can be enjoyed both in this field and in others fields of innovation. The growth of the green economy requires existing sectors to be transformed with the emergence of cleaner products and production technologies (the emergence of a low-emissions technology in the automotive sector) and the birth and expansion of new sectors (the production of solar panels).

Aghion et al. (op.cit.) emphasize the notion of temporal dependence for the emergence of new industries; companies tend to invest in the technologies with which they are familiar,

\footnotetext{
${ }^{17}$ Broner F., P. Bustos and V. Carvalho (2012): Sources of Comparative Advantage in Polluting Industries, Mimeo.

${ }^{18}$ See Aghion P., A. Dechezleprêtre, D. Hemous, R. Martin and J. Van Reenen (2012): “Carbon Taxes, Pathdependency and Direct Technical Change: Evidence from the Auto Industry", NBER Working Paper, no 18596, December.

${ }^{19}$ See Porter M.E. and C. Van der Linde (1995): "Toward a New Conception of the Environment-Competitiveness Relationship", Journal of Economic Perspectives, vol. 9, no 4, pp. 97-118.
} 
namely "dirty" products and processes. It is therefore important that clear and early indications of the new directions to take be given. Having said that, it is difficult to document this process of "re-specialisation" as it is already under way, notably because it consists of a series of diffuse and therefore as yet poorly evaluated processes. It is not currently possible to confirm that the "Porter effect" is a matter of basic fact. Indeed, it is difficult to empirically prove that the early adoption of environmental requirements would "automatically" be a way of creating strategic advantage in international competition. We can, however, on the one hand, document how the introduction of realistic energy pricing stimulates innovation and, on the other hand, note that this process is currently a very active one.

Realistic pricing: based on American data, Popp (2002) ${ }^{20}$ shows, for example, that over the 1970-1974 period, a $10 \%$ increase in energy prices resulted in an average 3.5\% increase in the number of patents filed in the energy sector, half of these in the first five years following the price increase. Likewise, Newell, Jaffe and Stavins (1999) ${ }^{21}$ showed that energy efficiency in 1993 would have been 25-50\% lower in air-conditioning units and gas boilers if energy prices had stayed at their 1973 levels. A more recent study by Dechezleprêtre et al. (2008) ${ }^{22}$ made similar observations based on the filing of patents between 1978 and 2003 in seven categories of renewable energy (wind power, solar, geothermal, marine energy, biomass, hydroelectricity and energy produced from waste) and six other fields contributing to the reduction in greenhouse gas emissions (destruction of methane, $\mathrm{CO}_{2}$ emission reduction processes for the manufacture of cement, energy efficiency in construction, injection engines, low-energy lighting and the capture and storage of carbon). Finally, Aghion et al. (op.cit.) show that an increase in the price of petrol encourages businesses to direct their innovation efforts towards "clean" technologies and away from "dirty" technologies; ${ }^{23}$ a $10 \%$ increase in the price of petrol increases the number of patents in the field of clean technologies by $10 \%$.

An active innovation process: studies by the OECD on green growth (op.cit.) show that the rate of innovation has increased for most of these technologies following the introduction of the Kyoto Protocol. This is particularly true of technologies such as wind power, certain solar systems, biofuels, geothermal energy and hydraulics. Furthermore, data relating to venture capital investment in green technologies highlights a high level of growth over recent years. In 2010, nearly a quar- ter of venture capital investment made in the United States related to clean energy technologies as opposed to less than $1 \%$ in 2000 , with key sectors including those of solar energy, transport, energy efficiency, biofuels, smart grids and energy storage.

The impact of regulation, taxation and, in fine, the cost of energy on economic players is reflected in a country's energy efficiency levels. At European level (Graph 3), that those countries with the highest levels of energy efficiency (the lowest TOE intensity per euro of GDP) are also those with the highest levels of energy consumption taxation (implicit tax in euros by TOE). Although the technological "performance" of marginal taxation is on the decline, there is clearly a decreasing relationship between taxation and energy intensity. In this respect, the situation of France is pretty average.

\section{Taxation of energy and energy intensity in Europe} 2010

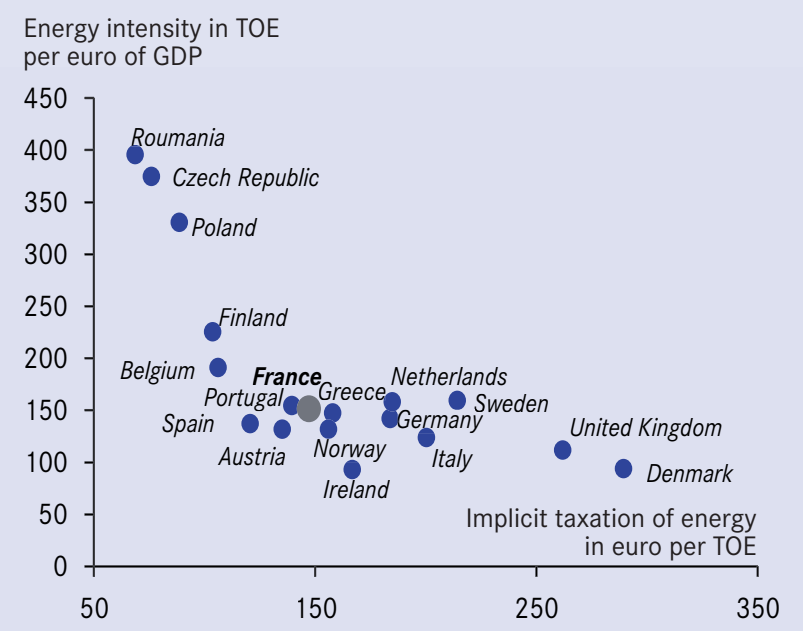

Source: According to Eurostat.

It should, however, be noted that the comparative advantages that will emerge around new or changing sectors depend heavily on the comparative advantages that currently exist in technologically similar sectors (see Fankhauser et al. 2012). With this in mind, Germany has developed a comparative advantage in the wind turbine sector based on its existing expertise in the field of high-precision machines. In this respect, there really is no "green" technology "miracle".

\footnotetext{
${ }^{20}$ Popp D. (2002): “Induced Innovation and Energy Prices”, American Economic Review, vol. 92, no 1, pp. 160-180.

${ }^{21}$ Newell R., Jaffe, A. and Stavins, R. (1999) “The Induced Innovation Hypothesis and Energy-Saving Technological Change”, The Quaterly Journal of Economics, vol. 114, no 3, pp. 3-29.

${ }^{22}$ Dechezleprêtre A., M. Glachant, L. Hasic, N. Johnstone and M. Yann (2008): Invention and Transfer of Climate Mitigation Technologies on a Global Scale: A Study Drawing on Patent Data, Report for the French Development Agency.

23 "Clean" technologies are those relating to electrical, hybrid and hydrogen-powered vehicles. "Dirty" technologies are those associated with vehicles with combustion engines.
} 


\section{How do variations in energy prices affect the competitiveness of French companies?}

Do energy price differences between competitors affect their export performance? The issues associated with competitiveness in the steel, aluminium, cement and fertiliser industries have come under particularly close examination in view of the implementation of the EU ETS, a unilateral European policy designed to fight climate change. Indeed, the "unilateral" nature of the policy was somewhat concerning for two reasons; on the one hand there was the concern not to excessively penalise the competitiveness of European industry and on the other the need to ensure that such policies would be effective in achieving their objective of reducing $\mathrm{CO}_{2}$ emissions, which would not be the case if emission-producing production activities were simply relocated, a fortiori to countries using less efficient technologies. This issue is known as "Carbon leakage". What interests us here is the impact of energy prices on export performance, rather than on carbon emissions.

In order to quantify the impact of increasing energy prices on competitiveness, we shall start by examining the aggregate trade data. Sato and Dechezleprêtre $(2013)^{24}$ use a sample of 21 years and 51 countries covering $80 \%$ of global trade, combined with data relating to energy prices for manufacturers in each country and for each type of energy (electricity, gas and fuel oil). They explain the export sales of each exporting country in each foreign market in terms of the difference in electricity prices and a series of regular control variables. Relatively higher electricity prices generally have a negative impact on exports out of the country imposing such prices, although this impact is limited. The elesticity is at most 0.2; for the most energy-dependent sectors ${ }^{25}$, a $10 \%$ increase in electricity prices reduces exports by $2 \%$.

Another approach involves exploiting companies' individual export data, which is the approach adopted in the present Note. What interests us here is the data relating to French exporters (i.e. those located in France) only. The energy dependence of each exporter is taken into account using that of the sector to which they belong. ${ }^{26}$ The analysis of individual data helps present a truly accurate picture of the impact of the increase in energy prices on French companies.

Clearly, not all industries are on an equal footing when it comes to an increase in the cost of energy. Sensitivity to an increase in energy prices relates directly to the use of energy and indirectly to the increase in the cost of intermediate consumption, which is itself energy-consuming. In this respect, the French automo- tive industry is affected through its own energy consumption and by the cost of the electricity used to manufacture glass and steel. Indeed, even the banking services provided to automotive manufacturers are themselves energy-consuming. In order to demonstrate this interdependence of economic activities and the distribution of increased costs throughout the economic fabric, we shall adopt an upper bound of the effects by outlining two hypotheses:

- faced with an increase in energy prices, companies do not immediately change their technologies;

- all intermediate consumption takes place in France and is therefore affected by the cost increase (Renault, for example, does not buy its steel from Russia). ${ }^{27}$

We shall then calculate the direct (the purchasing of electricity by the automotive industry) and indirect (the purchasing of electricity by those supplying glass to the automotive industry) energy content (in terms of value) of the production activities of each industry.

Graph 4 shows the sectors for which energy accounts for at least $10 \%$ of the production cost. The energy production sectors (refineries and electric power stations) have been excluded. The graph shows that after minerals, the second most heavily affected sector is fishing. Service sectors, such as air and sea transport, also feature. The most heavily affected manufacturing industry is chemicals, with the paper industry coming in second. In both of these sectors, energy accounts for around a fifth of the production cost. The metalworking, aluminium, rubber and food-processing industries are also very sensitive to the price of energy. Among the other sectors affected, agriculture is more heavily affected than the food-processing industry, the textile industry, the wood processing industry and even the IT industry. The proportion of energy is therefore less than $10 \%$ for all those sectors not shown here, which include, in decreasing order, automotive, electrical machinery, metalworking, furniture and other industries, leather and shoe-making, publishing, telecommunications equipment, other machines, clothing, other transport equipment, precision instruments and tobacco.

We shall now look at how the export activities of French companies operating in sectors with different levels of energy dependence are affected by energy prices. The method and the results are summarised in box 2 . The primary results are as follows:

- all other things being equal, a 10\% increase in electricity prices in France reduces the value of exports by an average $1.9 \%$, an estimation that reflects that of Sato and Dechezleprêtre (2013). We calculate a drop in exports of $1.1 \%$ for a $10 \%$ increase in gas prices;

\footnotetext{
${ }^{24}$ Sato Misato and Dechezleprêtre A. (2013): “Asymmetric Industrial Energy Prices and International Trade”, LSE Working Paper.

${ }^{25}$ The energy dependence of each sector is calculated using US data. The assumption is then made that the energy dependence of a particular sector is identical in every country in the world. This assumption helps correctly identify sector-specific elasticities.

${ }^{26}$ In order to avoid the endogeneity bias, energy dependence was measured in 2000 whilst the estimation itself begins in 2001.

${ }^{27}$ In technical terms, this choice is justified by the unavailability of detailed input-output tables that distinguish between the origins of the products in question. We shall refrain, here, from using the so-called rule of "proportionality".
} 
- this effect is noticeably greater for the largest exporters and in particular those belonging to heavily energydependent sectors; ${ }^{28}$

- a more rapid increase in electricity prices in France than in other countries has a negative impact, particularly on the export activities of the largest French exporters belonging to the most heavily energy-dependent sectors. The same cannot be said of gas prices. ${ }^{29}$

On this basis it is possible to assess the impact of an increase in industrial electricity prices in France. We can therefore estimate the effect of an anticipated 20\% increase in electricity prices $^{30}$ for manufacturers by 2017 as estimated by the French Energy Regulatory Commission (CRE). Such an increase would reduce the value of French exports excluding energy by $3.8 \%$. Based on the value of French non-energy exports in 2012, the cost in export activity of a $20 \%$ increase in electricity prices in France, all other things being equal, would therefore amount to some $€ 16 \mathrm{bn}$ and would primarily affect the largest exporters in the most energy-intensive sectors.

\section{Total energy content of branch production 2007}

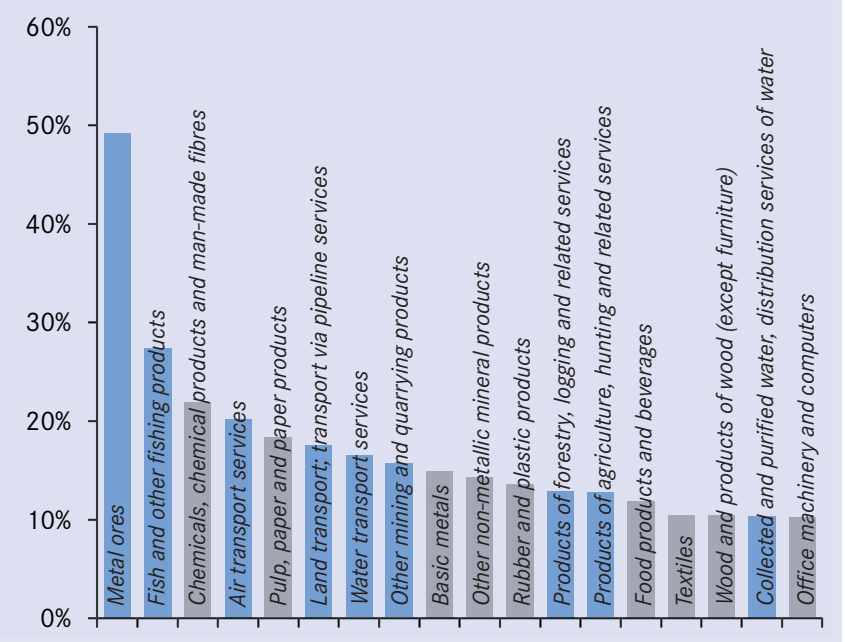

Reading: Manufacturing industries in grey.

Source: According to the INSEE's table of French imports and exports.

It is also possible to estimate the impact of the difference of around $30 \%$ on the average cost of production per MWh, between the scenario involving the accelerated decommissioning of the legacy nuclear network and that whereby its replacement is primarily postponed until after 2030. Supposing that taxes remain the same and that this increase in cost is passed on to manufacturers, the increase in the price of electricity resulting from this accelerated decommissioning would be around $20 \%$, again resulting in a drop in export activity of around $3.8 \%$.

These estimations would suggest that electricity prices have a significant impact on competitiveness. The transformation of companies towards more energy-efficient production methods is certainly a desirable possibility and could partially reduce the long-term effects but the short-medium term effects cannot be overlooked.

Energy costs affect different industrial sectors in very different ways since energy represents only a limited proportion of the costs incurred in many sectors. Other intermediate consumption, and indeed employment costs, account for a significant part of these overall costs. Manufacturing industries are ranked in Graph 5 according to their increasing (direct) work intensity (based on the total wage bill in relation to the value of output). This demonstrates that with the exception of the chemicals, metalworking, aluminium and paper industries, the cost of the energy used to produce is nevertheless modest in relation to the cost of employment.

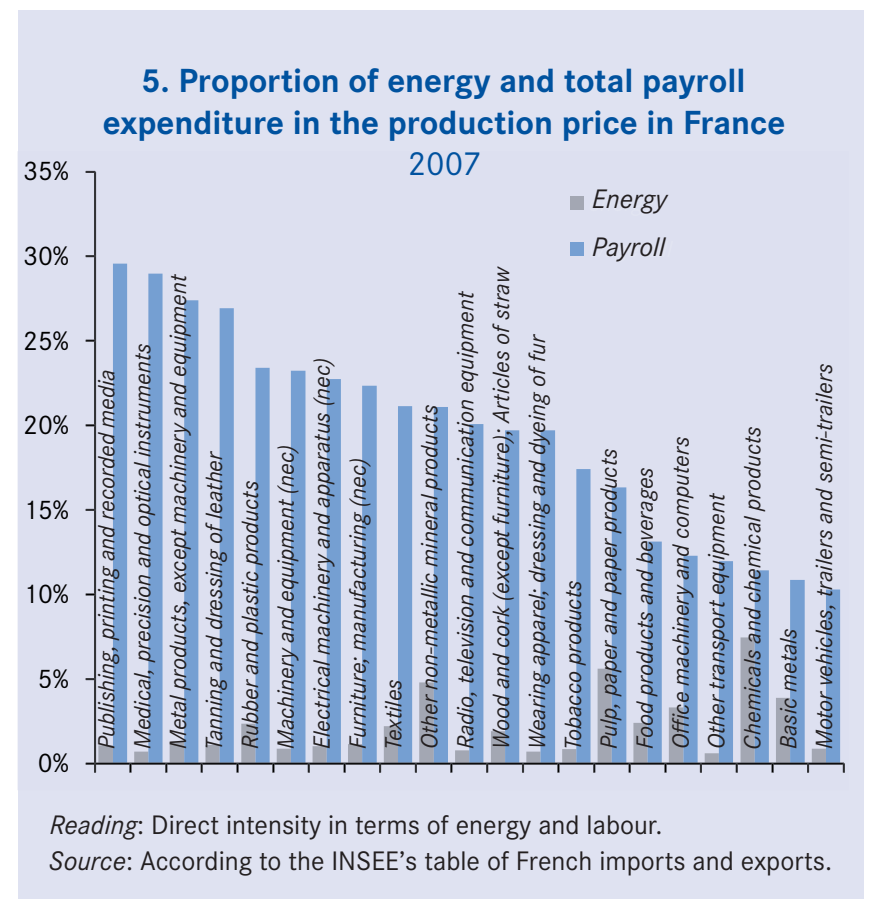

This comparison really comes into its own when comparing the taxation of the two production factors in question, namely labour and energy. Graph 6 indicates from an international comparison perspective the ranking of countries in accordance with the levy rate applicable to the two production fac-

\footnotetext{
${ }^{28}$ This becomes apparent by means of estimation involving the top $15 \%$ of flows in terms of value, market by market.

${ }^{29}$ This becomes apparent when interacting the size of the company with the level of energy dependence and the price of electricity in an equation incorporating the annual fixed effects of the destination country.

${ }^{30}$ We shall take the average of the anticipated increases of $24 \%$ in the tarif jaune and $16 \%$ in the tarif vert.
} 


\section{Gauging the sensitivity of French exports to the price of electricity}

We are looking at the exports in terms of value of each French exporter (there are some 100,000 every year) to each market (there are some 200 potential markets) over the 2001-2007 period. This data is recorded by customs authorities and combines the sales achieved by each exporter in a given year for a particular product category and destination. We do not have the information for sales of services. We shall therefore explain the variations in sales from one year to the next by a series of control variables specific to the destination or the year in question and the variation in the price of electricity, both alone and taking the original energy dependence of the sector into consideration (in order to take into account the fact that an increase in prices will have a stronger impact on the most energy-dependent sectors). We can therefore estimate the impact on exports of a variation in energy prices. Our analysis will cover the period up to 2007 only so as not to take into consideration the erratic developments in international trade observed during the 2008-2009 crisis. A number of sensitivity analyses have been performed.

We shall refer here only to the factor used to quantify the impact of the $20 \%$ increase in electricity prices ${ }^{a}$. We shall regress the value of exports (in logarithm form) of a company $f$ in a sector $s$ to country $i$ over the course of year $t$.

The variables are in logarithm form. The price of electricity is the French price. The equation incorporates fixed effects (sector-specific, destination country-specific) and a time trend. The coefficients are significant at the $1 \%$ threshold, with the exception of the variable relating to the interaction between price and energy dependence, which is not significant with this specification. It only becomes significant (at the $1 \%$ threshold) when the sample is restricted to the $15 \%$ largest market exporters.

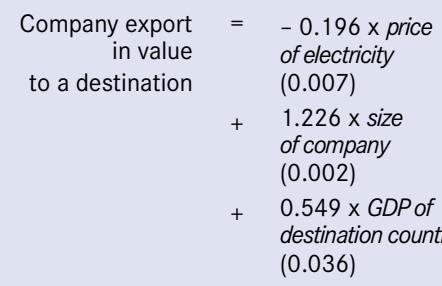

In brackets: standard deviation on the corresponding estimate.

a For a more detailed technical analysis see Fontagné L., P. Martin and G.L. Orefice (2013): French Exporters and Energy Costs, Miméo. This data was exploited at the CEPII. tors. France is shown to tax labour very heavily and energy less so. The data shown in Graph 6 does not take into account the competitiveness and employment tax credit (CICE) that has been in force since 1 January 2013 and equates to a reduction in social contributions. Although the CICE does not challenge the observation of a high level of taxation on employment in France, it is a step in the right direction. This international comparison places the impact of the cost of energy on competitiveness in its rightful context, particularly where the cost of labour is concerned. This brings us to the recommendation that the additional taxation of energy be used to reduce the cost of labour in accordance with the recommendations of the recent Note published by the $\mathrm{CAE}^{31}$ on the reduction of social contributions aimed at low earners. Indeed, whilst industrial exporters might employ more skilled workers, service costs, which are high in the case of unskilled workers, account for more than half of all costs incurred by exporters.

One major performance-related aspect concerns the composition of the export sector, which, strictly speaking, differs from competitiveness. Global demand can vary in terms of dynamism from one sector to the next (and even from one product to the next within a given sector); the sectoral (and indeed product-specific) targeting of the offering therefore goes some way to explaining combined performance. At a time when global energy prices have greatly increased since 2000 , it is therefore perfectly justifiable to wonder about this composition effect; are the most energy-dependent sectors those that have lost the most in terms of market shares (in relation to Germany)? In reality, excluding the success of the leather, leather goods and shoe sector already mentioned, there is no indication that the most heavily dependent sectors have performed any less well.

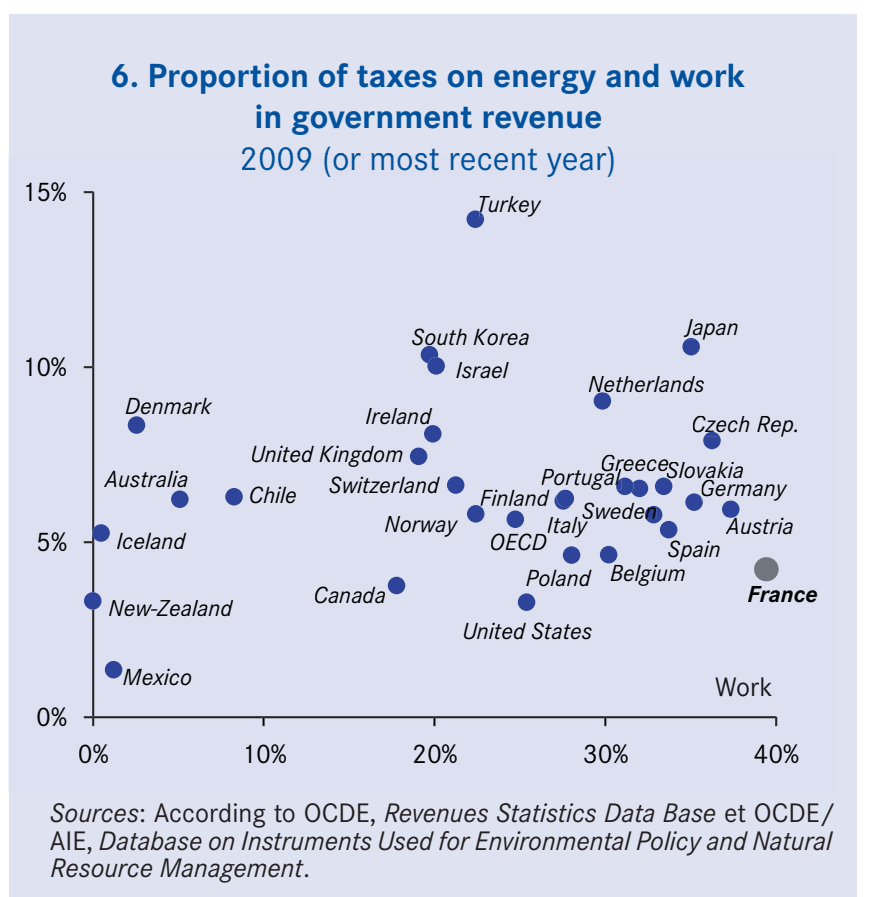

\footnotetext{
${ }^{31}$ Cahuc P., S. Carcillo and K.F. Zimmermann (2013): “L'emploi des jeunes peu qualifiés en France”, Note du CAE, no 4, April.
} 


\section{Recommendations}

We have shown that in the event of energy prices increasing to a greater extent in France than in rival countries, the short-term price competitiveness of French industry would be penalised, resulting in a decline in both export activity and employment. However, at a time when energy prices are expected to increase by $50 \%$ (with the exception of coal) over the next twenty years, directing industrial innovation efforts and goods and service production towards energy-saving initiatives is absolutely essential with regards to the dynamics of competitive advantage.

The tension between these two requirements, namely remaining competitive in today's world whilst preparing for the future, requires the right signals to be sent to economic players. It should be borne in mind that the price of energy is a short-term cost and a long-term signal. A high energy price, or the anticipation thereof, is an incentive to invest in new technologies, new products and new services. There are seven propositions that we would draw from this.

1. The increase in energy prices should be announced so that economic agents can adjust their calculation data. In this respect, the recent announcement by the CRE of future increases in the price of electricity for different types of users expected to be implemented by 2017 is an appropriate form of communication.

2. The increase should be announced in a credible way; energy prices should therefore start to increase immediately, at least to the extent that our competitors' energy prices are increasing, but the increase should be gradual. This policy would lose all credibility in the event of a delay. In this respect, the recent episode of the tax reduction applied to the price of fuel is a prime example of an undesirable policy.

3. The signal must be sent to both the consumer (to create an opening for product innovations) and the producer (to encourage process innovation). It is also important to ensure that the signal reaches those areas with the greatest potential for gains in terms of both efficiency and innovation.

4. The very specific situation of France, namely the high taxation of employment and the low taxation of energy, would lead us to recommend that the additional taxation of energy be used to reduce the cost of employment. This shift in taxation should, however, be a gradual one.

5. We have shown that an increase in electricity costs affects the performance of industrial exporters, an observation that should encourage a cautious approach with regards to the rate at which legacy nuclear facilities, the cost per kWh of which is particularly attractive, are decommissioned. It is important that choices regarding decommissioning be made based on an assessment of safety conditions carried out under the supervision of the French Nuclear Safety Authority but also that they take into account the effects on economic competitiveness documented in the present report.

6. A differentiated attribution of the public service charge (including funding for the development of renewable energy sources) according to energy intensity is perfectly justifiable and could exceed existing caps, as is the case in Germany. It would also be preferable for approaches at European level to be converged where network costs are concerned.

7. The future of energy prices will also depend on innovation in terms of the production of energy and not just the consumption thereof. Once the defence of dynamic competitive advantage is accepted, the issue of sunrise industries and public regulation must be addressed. The "precautionary principle", equated with the zero-risk impetus, as it often tends to be in French policy, can hinder the development of new sectors, growth and even employment. For want of short-term exploitation, research should be carried out into techniques for exploiting shale gas, in accordance with one of the recommendations of the Gallois Report.

Let us end by highlighting the fact that the increase in energy prices affects companies and households in different ways. With this in mind, an increase in energy taxation combined with a reduction in social security contributions would place a burden on households, which would only partially benefit from the reduction in charges (by means of the increase in employment or wage increases). This, of course, raises the issue of energy poverty, an issue that exceeds the scope of the present Note and should be examined in later works. Systems other than the temporary reduction in fuel tax can be used to deal with the issue of energy poverty among low-income households. The allocation of a fixed allowance of the kind already implemented in the United Kingdom would be easy to administer and gives the consumer the choice of whether or not to use this allowance to purchase energy (which tends to result in energy savings). On the other hand, deadweight effects are not to be ruled out. The bonusmalus system as it applies to the gas pricing structure adopted in France resolves the issue of deadweight effects but does not help redirect consumption; moreover, the body of information required to guide this policy presents a problem with regards to its implementation.

\section{conseil d'analyse économique}

Chairperson Agnès Bénassy-Quéré

Secretary general Pierre Joly

Scientific Advisors

Jean Beuve, Clément Carbonnier,

Jézabel Couppey-Soubeyran,

Manon Domingues Dos Santos,

Cyriac Guillaumin, Stéphane Saussier

The French Conseil d'analyse économique (Council of Economic Analysis) is an independent, non partisan advisory body reporting to the French Prime Minister. This Council is meant to shed light upon economic policy issues, especially at an early stage, before government policy is defined.

Members Philippe Askenazy, Agnès Bénassy-Quéré, Antoine Bozio, Pierre Cahuc, Brigitte Dormont, Lionel Fontagné, Cecilia García-Peñalosa, Pierre-Olivier Gourinchas, Philippe Martin, Guillaume Plantin, David Thesmar, Jean Tirole, Alain Trannoy, Étienne Wasmer, Guntram Wolff

Associated members Patrick Artus,

Laurence Boone, Jacques Cailloux
Publisher Agnès Bénassy-Quéré

Editor Pierre Joly

Electronic publishing Christine Carl

Contact Press Christine Carl

Ph: +33(0) 142757747

christine.carl@cae-eco.fr 